\section{ECONOMICS}

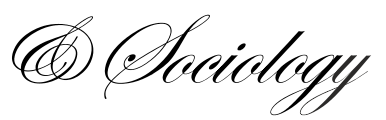

Guzal-Dec, D., \& Zbucki, Ł. (2021). Economic culture of Local Action Group (LAG) communities from peripheral regions. Evidence from Poland. Economics and Sociology, 14(3), 72-88. doi:10.14254/2071-789X.2021/14-3/4

\title{
ECONOMIC CULTURE OF LOCAL ACTION GROUP (LAG) COMMUNITIES FROM PERIPHERAL REGIONS. EVIDENCE FROM POLAND
}

Danuta Guzal-Dec

Faculty of Economic Sciences,

Pope John Paul II State School of

Higher Education in Biala

Podlaska, Biala Podlaska, Poland

E-mail:

danuta_guzal-dec@wp.pl

ORCID 0000-0002-2143-1649

Lukasz Zbucki

Faculty of Economic Sciences

Pope John Paul II State School of

Higher Education in Biala

Podlaska, Biala Podlaska, Poland

E-mail: zbuckilukasz@op.pl

ORCID 0000-0001-8426-6479

Received: March, 2021

1st Revision: April, 2021

Accepted: June, 2021

DOI: $10.14254 / 2071-$

789X.2021/14-3/4
ABSTRACT. Studying economic culture fills in the research gap that refers to understanding how soft factors of the European Union's LEADER Programme influence economic growth. The aim of this paper is to present the regional specifics of selected economic culture elements of Local Action Group (LAG) communities from the peripheral regions of Eastern Poland. The research was based on literature analysis, the diagnostic poll method, and statistical analysis (measures of descriptive statistics and the Kruskal-Wallis ANOVA test). The features of economic culture exhibited some similarities in the selected voivodeships, but each of them also had its own characteristics. The normative system in particular voivodeships should be considered internally differentiated at the average level. Such a situation can create positive conditions for LAG development wherever the level of norms acquisition is high (mainly in the Podkarpackie and Lubelskie Voivodeships). In Warmińsko-Mazurskie, the level of trust in agents and organisations beyond LAGs (as prospective cooperation partners) is relatively low. The research outcomes can be the premise to suggest ways and mechanisms for LEADER Programme implementation at the regional level, such as: strengthening identification with the LEADER normative system as well as shaping the normative system in terms of norms referring to the area of economic activity; increasing the bridging social capital component, as this, in particular, seems to be crucial for the ability of organisations to grow and innovativeness.

JEL Classification: Z10, O15 Keywords: economic culture, social capital, European Union's LEADER Programme, the Eastern Poland Macro-Region 


\section{Introduction}

The social sciences provide us with several types of definitions describing peripheral regions according to the different criteria. In both economic and political dimensions, they are described as areas that are not only distant and hard to access, but also economically dependent on economic and political centres (Idczak, 2013). In Poland, the following voivodeships show peripherality in terms of space and economy: Lubelskie, Podlaskie, Podkarpackie, Świętokrzyskie, and Warmińsko-Mazurskie. They are situated directly next to (or very near to) the eastern border of Poland, which is, at the same time, the eastern border of the European Union (EU). The above-mentioned regions, due to their specific nature (peripheral not only in the spatial but also in the economic dimension), are subject to state aid under EU regional and cohesion policies.

These five regions from Poland belong to the least developed regions of the EU (the so-called lagging regions), with clearly visible unfavourable features of peripherality in its various areas. The lagging regions also include regions from countries such as Bulgaria, Romania, Hungary, Greece, Italy, and Portugal. The specificity of development problems in these regions is most often associated with the post-industrial and typically agricultural nature of economies and the peripheral location. (Farole et al., 2018; Pilati \& Hunter, 2020). In the case of regions from the CEE countries, the additional developmental delay results from the shifts necessitated by the process of economic transformation from a centrally planned economy to a market economy. Years of operating within the bounds of the centrally planned economic system has left a specific legacy of insufficient development of pro-competitive entrepreneurial behaviour (economic culture) in society.

In the group of the five voivodeships surveyed, the Warmińsko-Mazurskie voivodeship is characterised by particularly difficult developmental conditions, especially with regard to the potential of human and social capital. The contemporary socio-economic situation of the Warmińsko-Mazurskie Voivodeship and its low competitiveness compared to the rest of the country can largely be explained by historical conditions. After the Second World War, under the centrally-planned economic system, former state-owned farms gradually became the basis for the development of the rural economy of this voivodeship. After 1989, along with the process of transformation of the country's economy, the following problems became highly visible in the Warmińsko-Mazurskie Voivodeship: progressive economic and social degradation of former state-owned farms and border areas, high capital intensity of agricultural production, decapitalisation of the means of production, low level of population wealth, and a low level of economic activity (Bartkiewicz et al., 2010).

However, the strive for improving cohesion and balancing the differences in development potential between the regions is not about the unification and elimination the characteristic features of the regions, but the use of their individual attributes in the development process (Hałasiewicz, 2011). There is a common consensus that seeking and animating the specific determinants of growth in the development process, that both the unit and the community are endowed with, and that refer to thinking and acting patterns in the area of economy, are defined as the economic culture (Kochanowicz, 2012; Kostro, 2009). Hence, the potential of both human and social capital, as referred to the economic activity, are a part of economic culture (Gardocka, 2005).

Among the set of informal values and ethical norms that create social capital, and that are common for a given group, trust is the most important one from the economic cultural development perspective. Trust determines cooperation, whose probability increases along with the level of trust in society (Putnam, 1995, p. 258). Trust extended beyond the social group or organisation (recognised within the so-called bridging social capital) has a particular meaning for economic growth. It determines the willingness to establish various social 
relations, and facilitates accessing and obtaining information that can contribute to building the diversified types of social capital resources. The lack of both bridging social capital and effective institutions regulating socio-economic relations is the reason for decreasing willingness to take new actions (especially in the economic sphere) (Growiec \& Growiec, 2011).

Social capital is one of the major factors conditioning the sustainable and multifunctional growth of EU rural areas. The major role it plays in its growth is assigned to the LEADER initiative that has been executed in the European Union since $1991^{1}$.

In its experimental phase between 1991 and 1993, LEADER involved 217 areas in designated disadvantaged rural regions. The encouraging results led to the applicability of the method being introduced in period 1994-1999 and expanded under LEADER+ (2000-2006) to cover all types of rural areas. In the period 2007-2013, the Leader Programme covered 2,416 rural territories across all member states. The programme is being continued in the future programming period (2014-2020, 2021-2027). It is based on seven principles: the bottom-up approach, the area-based approach, local partnership, integrated and multi-sectoral strategy, networking, innovation, and cooperation (https://enrd.ec.europa.eu/leader-clld_en ).

The bottom-up approach is at the heart of LEADER. LEADER conceives that local people are the best experts to drive the development of their territory. This bottom-up approach means that the local community and local players can help define a development pathway for their area consistent with their needs, expectations and plans. Doing this through a collective approach with delegated decision-making enables them to take charge of their own area's future. They make decisions about the local strategy and the selection of the priorities to be pursued. (...) The involvement of local actors should be fair and transparent including the population at large, economic, civic and social interest groups, and representative public and private institutions (https://enrd.ec.europa.eu/leader-clld_en).

Local Action Groups (LAGs) are the tool for the LEADER initiative's implementation. LAGs are organised as tripartite (civil, governmental, and business) rural development partnerships. In their functioning, they implement the main principles set out by the LEADER Programme, such as: area-based, bottom-up, public-private partnership, innovation, integration, networking, and co-operation (https://enrd.ec.europa.eu/leaderclld_en ). The LEADER approach is seen as a paradigm shift oriented towards the social and cultural construction of the territories' institutional capacities (Labianca et al., 2016), whose application has had a significant impact on the governance of predominantly rural European regions. Such an approach is based on the creation of a sense of identity and responsibility of residents for their local area (Chmieliński, 2011, p. 121).

Moreover, the contribution of the LEADER initiative to the creation of social capital, so often emphasised in the literature, also allows the generation of positive effects in the area by improving the situation in rural labour markets thanks to job-creation opportunities. The LEADER Programme also supports other activities aimed at facilitating entrepreneurship in rural areas. Beneficiaries receive support for the organisation of trainings, research for local markets of goods and services, promotion of local entrepreneurship, starting production, and marketing of goods and services based on local resources, traditions, and heritage (Guzal-Dec \& Zwolińska-Ligaj, 2018).

To date, the research has pointed out both positive and negative results of the LEADER Programme ${ }^{2}$ (Guzal-Dec \& Zwolińska-Ligaj, 2018). As, for example, Bosworth et al. (2016) claimed, measuring and understanding how "added value" is generated is

\footnotetext{
${ }^{1}$ In Poland, the LEADER initiative was implemented in 2004, along with the Poland's access to the European Union, contributing to the LAGs appearance and growth - 324 organisations registered by 31.12.2019.

${ }^{2}$ Guzal-Dec \& Zwolińska-Ligaj "The impact of LEADER Programme on entrepreneurship and employment in the context of multifunctionality of rural areas. A case study of EU peripheral region (lubelskie voivodeship, Poland)"
} 
problematic (Elliott, 2010; Report..., 2012), with purely economic measures showing relatively low job creation ${ }^{3}$ and high costs per job created (Krievina et al., 2015). By contrast, evaluation focusing on LEADER benefits in a broader sense indicates more positive values, such as the creation of social capital (e.g. Anderson et al., 2014; Guzal-Dec, 2014; Lafleur \& Merrien, 2012; Teilmann, 2012) and a range of non-economic results for rural communities (Bosworth et al., 2016; Nembhard, 2014). Furthermore, in light of the national evaluation reports and yet another examination, it has been argued that although the measurable economic effects of LEADER interventions might be small, their impact can make a real difference for local communities (e.g. Bosworth et al., 2016; Krievina et al., 2015; Report, 2012).

With the confirmed imbalance of the LEADER Programme's influence on economic versus social development, further studies should be undertaken immediately, with the focus on seeking ways to enhance the impact on rural areas' economic animation, including the peripheral regions in particular. Studying the economic culture can fill in the existing gap in terms of searching for the soft factors of the LEADER Programme that influence the economic growth of rural areas.

This paper poses the question of how the LAG communities' economic culture from the peripheral regions of Eastern Poland is shaped, with reference to the selected features of human and social capital. The high level of respect for values such as: diligence, code of conduct, work esteem, cost efficiency, entrepreneurship, risk-taking, openness to changes, innovative approach to action, as well as high homogeneity of the set of norms respected by the particular LAG representatives (social, economic, and NGO sector), can contribute to enhancing LAGs' influence on local and regional system development. The aim of this paper is to present regional specifics of the selected economic cultural elements of the Local Action Groups (LAGs) communities from the peripheral regions of Eastern Poland. Supporting this thesis about the regional diversity of economic culture (Krzemieniewska, 2014), a comparative analysis including five peripheral voivodeships in Eastern Poland was performed. Despite the fact that these regions have several economic features in common (they are all peripheral), and geographically they are located close to one another, still, they remain under the influence of different cultural factors.

This paper is organised in the following way: the first section briefly presents the theoretical background concerning the economic cultural influence on socio-economic growth; next, the methodology used in the empirical research is described; and lastly, it is followed by the presentation of the research findings. Some concluding remarks can be found in the last section.

\section{Literature review}

According to Porter, economic culture consists of the set of beliefs, attitudes and values that are connected with economic activity (Porter, 2003, p. 59). The economic culture appears and changes under the influence of homo oeconomicus, who creates it, keeps it alive, modifies it, and passes it on from generation to generation. Due to its specific nature,

\footnotetext{
${ }^{3}$ As the Latvian practical example shows, the implementation of the LDS in the 2007-2013 period was not balanced: at the planning level, priorities and activities of LDS widely covered entrepreneurship development, though among the implemented projects, economy-related projects accounted for only about $18 \%$ of the total approved financing. Most of LEADER projects have been implemented to facilitate the development of infrastructure related to active recreation and quality leisure time, as well as culture and sports (Krievina et al., 2015); As far as the Polish example is concerned (GuzalDec \& Zwolińska-Ligaj, 2018), the study of LAGs' operations in the Lubelskie Voivodeship in the period 2007-2013 and their impact on the development of entrepreneurship and job creation in rural areas revealed that the LAGs' contribution to the creation of new entities should be assessed as small. The majority of LAGs in question demonstrated lower than average activity in applying for funds aimed at the creation of new jobs.
} 
economic culture is non-autonomous, dependent, and derivative, which means that it can exist only within the community of a given economy based on the real existence of economic agents and material objects, and it is generated by the unit and its community (Gardocka, 2005). Economic culture, in such a sense, is the system common to a given community that uses given production relations and values held in behavioural patterns and material objects. It determines aims and methods of conduct in the area of economic activity, and it shapes the set of values and mechanisms of implementing values valid in the culture (Krzyminiewska, 2014, p. 82). Hence, with economic culture defined as the way social units and communities think and act in the economic field, it can be claimed as the economic development factor. Within its scope, it comprises a sequence of important variables that can be crucial for the prospective ability of a given population to take part in the economic process and achieve the competitive advantage of a given community and society as a whole (Krzyminiewska, 2014).

Each unit belongs to various social groups, and its mind is programmed in many fields corresponding to different levels of culture (Hofstede, 2000, p. 46). The level of national culture is the main economic subject of study (the criteria and basic values are created to identify the profiles and dimensions of national cultures (Gesteland, 2000; Hofstede, 2000); researching the regional cultural level is less popular. However, in sociology and management, the issue of the level of organisational culture is being analysed very often.

Within the context of research on the factors conditioning socio-economic growth, economics and other social sciences make attempts to identify the values that might facilitate or hinder economic development; they even try to create models of pro- and anti-development cultures (Grondona, 2003, pp.105-113; Harrison, 2003, pp. 434-435). It is also stressed that only nations having value systems promoting development are able to keep long-term economic growth (Grondona, 2003, pp. 102-103). Culture is the factor that, to a large extent, determines the ability of a given nation to grow successfully because it shapes the units' beliefs about risk, gratification, and the accessible possibilities. The cultural values are crucial in the society's development process as they influence the units' way of thinking, considering progress, and economic development (Lindsay 2003, p. 412). Progressive cultures accentuate the meaning of the future; on the other hand, the present and the past are the most important in conservative cultures. The future-oriented approach results in the progressive worldview: control over one's own destiny.

While distinguishing between economically progressive and conservative cultures, the attitude towards the basic economic and economy-related categories should be defined. They are: the sources of wealth, work, work esteem, cost efficiency, code of conduct, trust as the catalyser for economic cooperation, and economic life democratisation. Economic growth widely depends on changing the way people think about generating wealth. Progressive cultures represent the view that wealth is generated by things that don't exist yet, or by innovative processes that have not yet started. In such cultures, work is the basis for a good life, and diligence, creativity, and achievements are not only a financial award, but also a source of satisfaction and self-esteem. In communities from progressive cultures, trust goes far beyond the community and becomes the trigger for its development and innovativeness. Progressive cultures are characterised by a stricter code of ethics. Justice and honesty are widely expected in human relations (Harrison 2003, pp. 434-435). Gathering information concerning the economic culture specific to a given community is crucial for adopting systemic solutions aimed at shaping its pro-developmental character.

The dependency between economic culture (manifesting itself in human and social capital) and socio-economic growth is positive. The analyses of international data have proven that social capital determines the future development of a country (Diagnoza..., 2009). However, it should be observed that such dependence is not revealed until a certain threshold of development has been exceeded. In poorer countries, economic growth is driven by the 
level of human capital (e.g. education, skills) rather than by social capital (e.g. trust, networks, civic involvement). It explains why the Polish economy has been growing at a considerable rate despite very low social capital (Czapiński, 2008). However, if Poland wishes to grow at such a pace, building social capital is a must. The rural areas and their inhabitants could slowly become a very significant factor in this growth.

The issue of positive reinforcement of socio-economic development by cultural factors (economic culture) is particularly complex in the cases of peripheral regions. It is connected with the fact that the manifestations of conservative cultures often dominate in such regions. According to the path dependence concept (Arthur, 1989), on the current development path, the regions in question are threatened by "being locked-in on the peripheral path" (Grabber, 1993). Hence, the cognitive lock-in is especially unfavourable. It is the result of cultural norms and beliefs developed in a given society that hinder or simply block the change of economic specialisation (e.g. the reluctance to innovate). However, research has proven the positive impact of culture on the entrepreneurial process in peripheral regions. The entrepreneurial potential of a region is the key factor in linking innovation to the market, thus leading to economic growth. This is especially vital for such peripheral regions where low innovative dynamism occurs (García-Rodríguez et al., 2017).

In conducting development policy for peripheral regions, it is necessary to constantly monitor and modify support mechanisms. The typically rural character of the region's economy is a potential factor of its economic peripheral nature. One of the initiatives aimed at the socio-economic development of rural areas is the LEADER Programme. So far, there have been numerous studies on the possible impact of the programme on the development of social capital (Pisani et. al., 2017) Studying economic culture fills in the research gap as to how soft factors of the LEADER Programme influence the economic growth of rural areas.

\section{Methodological approach}

The research was based on literature analysis, the diagnostic poll method, and statistical analysis. In order to examine the diversity of selected features of economic culture in particular voivodeships, such tools as the measures of descriptive statistics (arithmetic mean and coefficient of variation [CV] and the Kruskal-Wallis ANOVA test) were used. The Kruskal-Wallis ANOVA test is a rank-based nonparametric test that can be used to determine if there are statistically significant differences between two or more groups (MacFarland \& Yates, 2016). The Kruskal-Wallis ANOVA test was used to identify the level of cultural norms acquisition by LAG communities in examined voivodeships.

The programme Statistica 13.3 version was used for calculations.

Data sources used and the empirical basis of the study consist: an opinion poll organized by author (primary data source) and as a secondary data source: Report of the Ministry of Agriculture and Rural Development in Poland (Abramowicz et al., 2019). The opinion poll was conducted by CBM INDICATOR.

The opinion poll was conducted between March and September of 2019 among the communities of $26 \mathrm{LAGs}^{4}$, which constituted $27.7 \%$ of the 94 LAGs functioning in the voivodeships from the Eastern Poland macro region. For each voivodeship, the sample was prepared proportionally to the general number of LAGs operating in a given region (25-30\%).

\footnotetext{
${ }^{4}$ According to voivodeships: 7 LAGs from Lubelskie (105 respondents), 7 LAGs form Podkarpackie (105 respondents), 5 LAGs from Świętokrzyskie (75 respondents), 4 LAGs from Podlaskie (60 respondents), 3 LAGs from Warmińsko-Mazurskie (45 respondents).
} 
In 26 LAGs researched, 390 direct surveys were made among the 1,112 active members ${ }^{5}$ out of the 3,052 officially registered LAGs' members. The low percentage of active LAG members is due to the fact that other rural organizations, such as rural housewives' clubs, often joined the organization. In practice, only the leaders of these organizations were actively involved in the work of LAGs at that time.

The minimal size of the representative sample (390 units) was determined with proportion $(\mathrm{P})=0.5$, confidence level $=0.95$, and sampling error $=0.04$.

The opinion poll conducted included the following elements of social capital analysis: level of norm acquisition and respect (on a scale from 0 to 5, where 0 is a lack of acquisition, 1 is a very low level of acquisition, 2 is a low level of acquisition, 3 is a moderate level of acquisition, 4 is a high level of acquisition, and 5 is a very high level of acquisition), referring to:

I. the normative assumptions of the LEADER initiative, in particular to: local patriotism, partnership, a sense of subjectivity, responsibility and empathy for the group, and respect for democracy in cooperation;

II. the area of economic activity, including: diligence, code of conduct, cost efficiency, entrepreneurship, risk-taking, openness to changes, and an innovative approach to action;

III. social trust, in particular: 1) LAG members' trust in people they are familiar with: a) LAG members from the same sector and b) LAG members from other sectors; 2) LAG members' trust in people they are not familiar with: trust in agents/organisations outside of the LAG as prospective cooperation partners.

In a narrower sense, analysis of the selected economic culture components includes the following:

- respecting the norms referring to the area of economic activity, as described in II above;

- the specific nature of trust exhibited inside and outside the LAG, as described in III above;

- the particular features of human capital.

In the comparative analysis of voivodeships in eastern Poland, it was assumed that:

Hypothesis 1. The Warmińsko-Mazurskie Voivodeship shows statistically significant differentiation in terms of negative phenomena in economic culture potential when compared to other regions.

The comparative analysis, concerning the selected elements of the structural characteristics showed in the study of a sample of LAGs from Eastern Poland voivodeships, takes into account the results of the surveys and the analyses conducted under the final evaluation of LAGs' functioning in Poland during the period 2014-2020, commissioned by the Ministry of Agriculture and Rural Development (Abramowicz et al., 2019). The results of the research were compared with the results of other authors dealing with the issues of the functioning of LAGs in Poland: Zwolińska-Ligaj and Psyk-Piotrowska (Psyk-Piotrowska, 2013; Zwolińska-Ligaj, 2018).

\footnotetext{
5 active in organisations and actively participating in taking common decisions (participation in general meetings) indicated by LAGs' management/LAGs' directors (personal lists constituted the sampling frame).
} 


\section{Conducting research and results}

\subsection{The LAGs' characteristics surveyed: The survey area}

The 26 LAGs surveyed covered the territory of 209 communes (gmina, NUTS 5 level) and over 1.6 million rural inhabitants. The distribution of the LAGs surveyed is shown in Drawing 1.

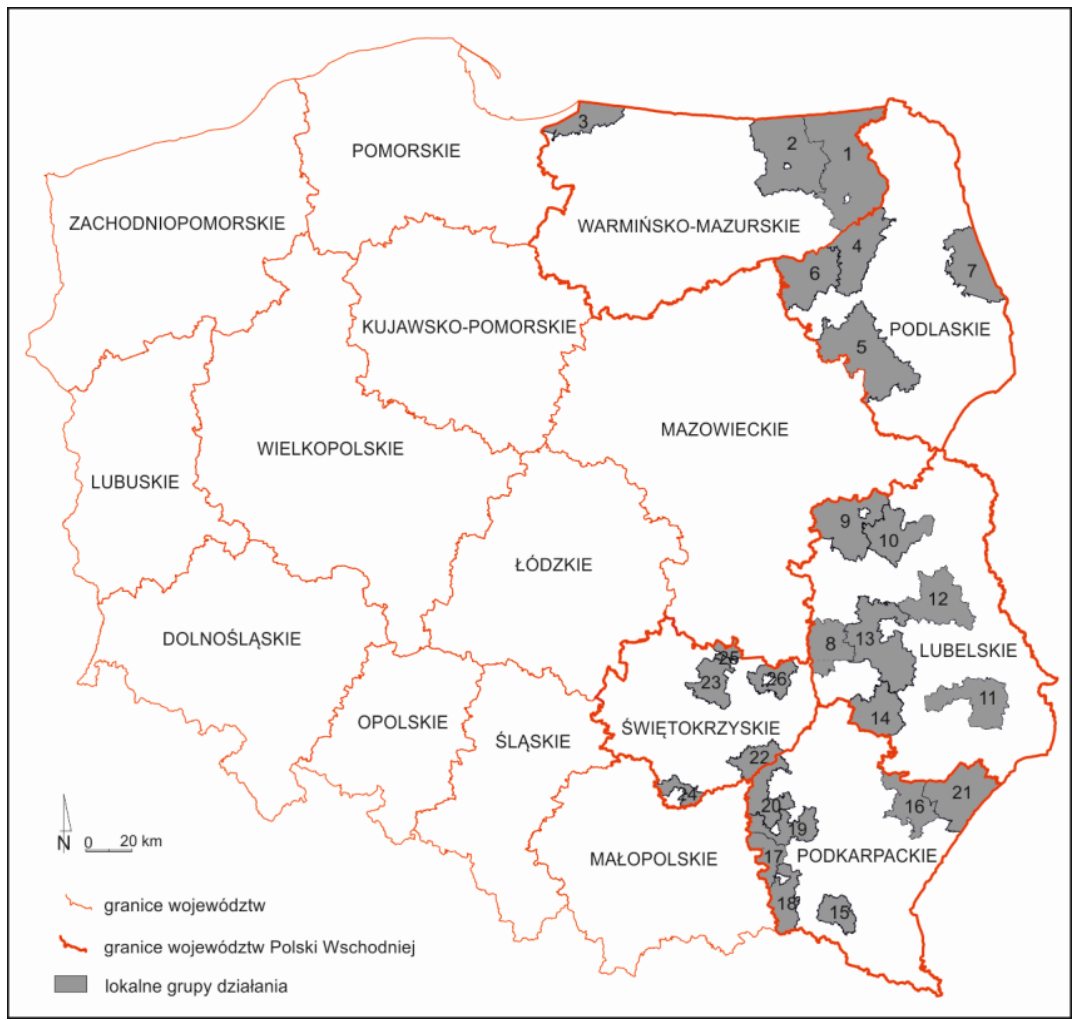

Drawing 1. The distribution of the surveyed LAGs in voivodeships (provinces) Source: compiled by Lukasz Zbucki

The smallest LAG surveyed covered the area of 4 communes, whereas the largest covered 16. The smallest LAG surveyed was inhabited by 34.4 thousand residents, and the largest by 143.5 thousand $^{6}$. In total, the members of the LAGs in question comprised over 3 thousand entities operating in the socio-economic sphere (public, private, and nongovernmental sectors).

\subsection{LAG community characteristics as referred to human capital potential}

The number of active members in the LAGs surveyed constituted $36.45 \%$ of the total number of registered agents. There were $52.8 \%$ of women and $47.2 \%$ of men in the research sample of active LAG members. The social sector was represented by $45.4 \%$ of the respondents, economic by $21.0 \%$, and public by $33.6 \%$. The above-mentioned results are in

\footnotetext{
${ }^{6}$ According to the act of law concerning CLLD (Community-led Local Development) (Dz.U. 2015 poz. 378 ze zm.), LAG range should include at least the area of 2 communes and be inhabited by a minimum of 30 thousand residents, not including the towns inhabited by more than 20 thousand residents. The maximum number of residents inhabiting a given LAG is 150 thousand people.
} 
line with the Polish results. A nation-wide final evaluation of the LAGs' functioning in the period 2014-2020 also indicates the fact that the actual level of LAG members' involvement was around $21-50 \%$, and the sectoral division of LAG members is not even. The residents who constitute more than $50 \%$ of members in $25 \%$ of communities are considered to be a well-presented sector. Keeping up the entrepreneurs' involvement seems to be the most difficult, and that is the group in which members fluctuate the most (Abramowicz et al., 2019, pp. 23-24).

Graph 1 presents the age structure of the sample.

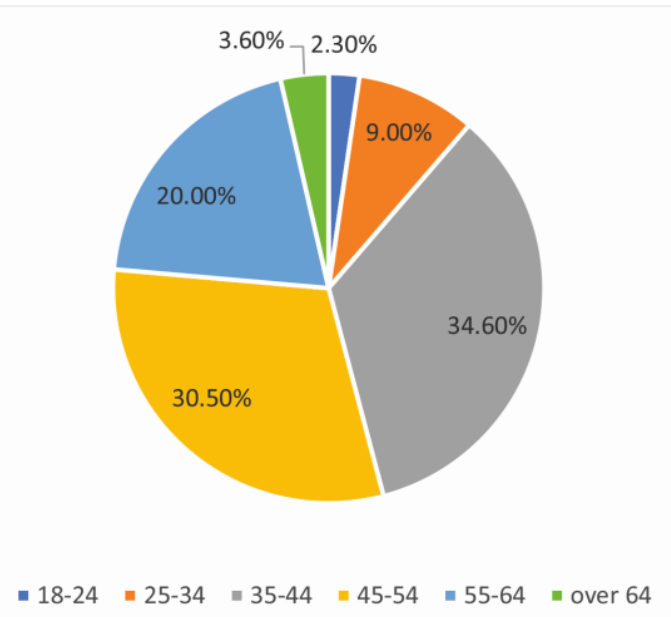

Graph 1. Age structure of the surveyed LAGs members ( $N=390$, total of sample)

Source: Own elaboration based on the empirical research

The most numerous groups in the researched sample were: $35-44$ years $(34.6 \%$ of the total number) and 45-54 years (30.5\% of the total number). Young people aged 18-24 constituted the smallest and relatively low share, which can be interpreted as an unfavourable phenomenon in terms of shaping social capital by the young generation in rural areas. However, the educational structure of the LAG members researched looks positive. $64.1 \%$ of respondents declared higher or incomplete higher education, $27.9 \%$ declared secondary education (vocational or general), 7.4\% declared basic vocational or incomplete secondary education, and primary or incomplete primary education was declared by only $0.6 \%$ of respondents. In each voivodeship, the proportion of respondents with at least secondary education constituted over $75 \% .96 .2 \%$ of those surveyed were professionally active.

The representatives of the research sample showed strong emotional attachment to their place of living. The majority (over $80 \%$ of respondents) declared a high and very high level of emotional attachment to their place of living. Only $2 \%$ of those surveyed showed a low level of attachment to their place of living and indications of a very low level of attachment did not occur. 


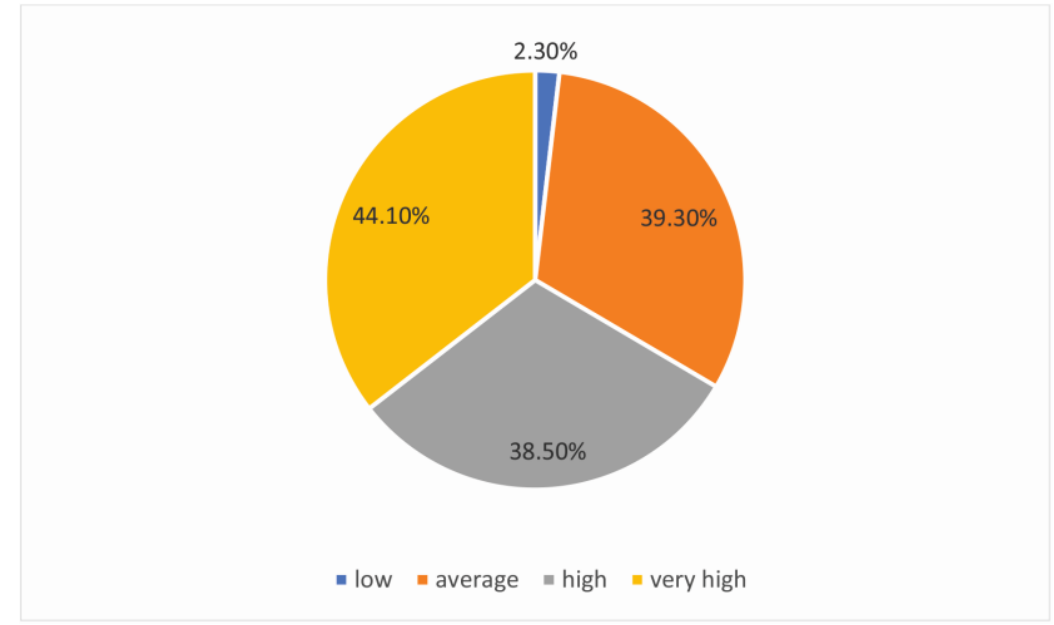

Graph 2. The level of emotional attachment to the place of living ( $N=390$, total of sample) Source: Own elaboration based on the empirical research

\subsection{The characteristic nature of the LAG community's normative system}

The analysis concerning respect for norms and values in LAG members' activity was performed as a comparative analysis according to the LAG's location in a given voivodeship. The comparisons were made by means of two measures of descriptive statistics: the arithmetic mean for estimating the average level of norms and values acquisition, and the coefficient of variation (CV) (standard deviation/mean * 100\%) to show the level of accordance with the system of norms, values, and attitudes respected by the particular representatives of the groups constituting LAGs. The low level of the coefficient of variation (below 20\%) indicates a low level of differentiation of the normative system.

The analysis concerning the respect for the norms and values constitutive for LAG existence, as well as the norms and values referring to the economic processes and manifestations of social capital that are included in the manifestations of the surveyed LAG members' economic culture, reveals some general regularities.

Firstly, attention should be paid to the fact that the highest level of the norms and values in question is observed in the Podkarpackie Voivodeship, with Lubelskie next in line. It has to be noted that, in general, the normative system respected by the given LAG members located both in the Podkarpackie and Lubelskie Voivodeships should be considered as that of higher inner homogeneity (low level of the coefficient of variation: below 20\%). In the cases of the above-mentioned voivodeships, the analysis of the social trust component shows that its level goes down along with going beyond the represented sector, and further, beyond the group. Nonetheless, it can be considered high (mean around 4.0). Risk-taking noted the lowest rate among the studied norms with a moderate level of acquisition (mean below 4.0).

LAGs from Podlaskie and Świętokrzyskie also show some similarities. Here, the level of norms and values acquisition remains at the moderate level (mean below 4), while the grades are more diverse inside the LAG (coefficient of variation at the moderate level: over $20 \%$ ). In the cases of LAGs from these voivodeships, the level of trust is also moderate (mean below 4), however, trust does not diminish while going beyond the sector and the group. 
Table 1. Declaration of respect for* norms and values in LAG members' activity according to the location in voivodeships ( $\mathrm{N}=390$, total of sample)

\begin{tabular}{|c|c|c|c|c|c|c|c|c|c|c|c|}
\hline \multicolumn{2}{|r|}{ voivodship } & \multicolumn{2}{|c|}{ Lubelskie } & \multicolumn{2}{|c|}{ Podkarpackie } & \multicolumn{2}{|c|}{ Podlaskie } & \multicolumn{2}{|c|}{ Świętokrzyskie } & \multicolumn{2}{|c|}{$\begin{array}{l}\text { Warmińsko- } \\
\text { Mazurskie }\end{array}$} \\
\hline \multicolumn{12}{|c|}{$\begin{array}{l}\text { norms/values } \\
\text { in surveyed categories }\end{array}$} \\
\hline \multirow[t]{5}{*}{ I category } & local patriotism & 4.39 & 16.41 & 4.43 & 17.81 & 3.87 & 22.77 & 3.79 & 26.21 & 4.18 & 17.27 \\
\hline & $\begin{array}{l}\text { responsibility for other } \\
\text { LAG members }\end{array}$ & 4.15 & 18.65 & 4.18 & 18.95 & 3.81 & 23.34 & 3.61 & 28.66 & 3.70 & 22.39 \\
\hline & $\begin{array}{l}\text { empathy towards the } \\
\text { disadvantaged groups }\end{array}$ & 4.08 & 19.54 & 4.16 & 20.69 & 3.76 & 25.43 & 3.61 & 24.35 & 3.73 & 33.18 \\
\hline & $\begin{array}{l}\text { respecting democracy in } \\
\text { taking common decisions } \\
\text { by LAG }\end{array}$ & 4.32 & 17.07 & 4.37 & 17.14 & 3.85 & 20.81 & 3.80 & 27.58 & 4.16 & 17.66 \\
\hline & $\begin{array}{l}\text { equal treatment of other } \\
\text { LAG members }\end{array}$ & 4.29 & 17.60 & 4.40 & 15.69 & 3.96 & 22.65 & 3.89 & 25.65 & 4.05 & 17.92 \\
\hline \multirow[t]{8}{*}{ II category } & diligence & 4.33 & 16.06 & 4.42 & 15.99 & 3.71 & 21.52 & 3.83 & 20.83 & 4.07 & 17.82 \\
\hline & code of conduct & 4.32 & 16.44 & 4.39 & 15.69 & 3.83 & 26.91 & 3.84 & 24.87 & 4.11 & 18.29 \\
\hline & work esteem & 4.34 & 17.38 & 4.41 & 16.10 & 3.87 & 23.49 & 3.78 & 25.68 & 4.29 & 15.59 \\
\hline & cost-efficiency & 4.33 & 17.37 & 4.43 & 16.08 & 3.74 & 25.97 & 3.77 & 25.57 & 4.13 & 17.37 \\
\hline & entrepreneurship & 4.20 & 18.54 & 4.24 & 16.38 & 3.80 & 21.97 & 3.84 & 25.70 & 3.81 & 22.57 \\
\hline & risk-taking & 3.85 & 20.31 & 3.88 & 21.22 & 3.67 & 25.39 & 3.68 & 23.68 & 3.37 & 24.50 \\
\hline & openness to changes & 4.17 & 19.45 & 4.23 & 18.86 & 3.69 & 21.88 & 3.75 & 26.48 & 3.71 & 21.04 \\
\hline & $\begin{array}{l}\text { innovative approach in } \\
\text { acting }\end{array}$ & 4.13 & 18.62 & 4.24 & 19.68 & 3.81 & 22.92 & 3.75 & 26.30 & 3.76 & $21 . .09$ \\
\hline \multirow[t]{3}{*}{ III category } & $\begin{array}{l}\text { trust in other LAG } \\
\text { members from the same } \\
\text { sector }\end{array}$ & 4.38 & 15.90 & 4.37 & 14.81 & 3.80 & 26.45 & 3.79 & 25.97 & 4.09 & 17.02 \\
\hline & $\begin{array}{lll}\begin{array}{l}\text { trust in } \\
\text { members } \\
\text { sectors }\end{array} & \begin{array}{l}\text { other } \\
\text { from }\end{array} & \begin{array}{l}\text { LAG } \\
\text { other }\end{array} \\
\end{array}$ & 4.31 & 16.84 & 4.27 & 15.75 & 3.77 & 23.58 & 3.70 & 28.37 & 3.84 & 18.22 \\
\hline & $\begin{array}{l}\text { trust in non-LAG } \\
\text { agents/organisations. as } \\
\text { the prospective } \\
\text { cooperation partners }\end{array}$ & 4.17 & 18.21 & 4.10 & 16.81 & 3.80 & 24.47 & 3.81 & 26.76 & 3.59 & 19.91 \\
\hline
\end{tabular}

(on a scale from 0 to 5, where 0 - the lack of acquisition, 1 - very low level of acquisition, 2 - low level of acquisition, 3 - moderate level of acquisition, 4 - high level of acquisition, and 5 - very high level of acquisition) Source: Own elaboration based on the empirical research

It should be pointed out that Świętokrzyskie has some certain specificities when compared to other voivodeships. In this case, the relatively low level of respecting the LEADER initiative's normative assumptions is revealed, including, in particular, local patriotism, partnership, the feeling of subjectivity, responsibility and empathy for the group, and respecting democracy in cooperation. At the same time, the lowest level of inner trust inside LAGs is observed, including inter-sectoral trust (in LAG members from other sectors).

The specifics concerning respect for norms and values are even more complex in LAG communities from Warmińsko-Mazurskie. Due to the peripheral character of the voivodeship in question, with post-PGR (former state-owned farms) communes constituting its biggest part and having a high share of socialised economy before the economic transformation in Poland, it is very alarming that in organisations where the basic objective is to improve social inclusion in rural areas, the empathy level towards disadvantaged groups is average, with members at a moderate level of agreement to respect this norm (coefficient of variation above 30 ).

In the case of Warmińsko-Mazurskie, some clearly negative phenomena in terms of shaping the economic cultural potential can also be observed. Study of the social trust component shows that the level of this value is lowering while going beyond the represented sector and further beyond the group, varying from high to moderate level, and the analysed level of trust in agents and organisations beyond LAGs (as prospective cooperation partners) is the lowest in this voivodeship when compared to the surveyed group. Risk-taking is also placed at a relatively low level. Entrepreneurship, openness to changes, innovative approach 
to action (the norms and values that are so important for economic culture) are acquired at a moderate level. Zwolińska-Ligaj (2018, p. 282) signalises a similar problem with the Warmińsko-Mazurskie Voivodeship in her study on the economic culture of companies from peripheral voivodeships: Podkarpackie, Lubelskie, and Warmińsko-Mazurskie (random sample 240). She indicates that the manifestations of economic culture are being shaped differently for entrepreneurs from Warmińsko-Mazurskie when compared to those from Podkarpackie and Lubelskie. As Zwolińska-Ligaj puts it, entrepreneurs from Lubelskie and Podkarpackie highly rated the range of respecting norms and values considered to be important for building companies' relations with the non-economic, local environment (and slightly lower, though still relatively high, norms and values facilitating the establishment of relations in a business environment with innovative actions). Entrepreneurs from WarmińskoMazurskie exhibited a significantly higher acquisition level of studied norms, values, and attitudes, especially in respect to those vital for the development of relations and cooperating with partners from the entrepreneurs' environment. They are also important for actions enhancing innovations in terms of openness to changes, innovative approach to action, entrepreneurship, openness to dialog, and risk-taking.

The surveyed sample of LAG communities from Eastern Poland's voivodeships also shows another regularity: the respect for norms referring to the area of economic activity, especially to risk-taking, is at a less advantageous level. Such attitudes are not favourable for LAG functioning if it is assumed that they should seek the sources of finance on their own in the situation of limited financial support under the LEADER Programme. Hence, it influences the shaping of a certain kind of autonomy in these organisations. Moreover, the level of respect for norms such as risk-taking, entrepreneurship, openness to changes, and innovative approach to action show the visible diversity between voivodeships. LAG members from Podkarpackie showed the highest level of acquisition, followed by Lubelskie and Świętokrzyskie; Warmińsko-Mazurskie had the lowest level. As Psyk-Piotrowska (2013) underlines, the key constraint of rural areas' socio-economic structure in WarmińskoMazurskie is social passivity, a demanding attitude which is quite common in the post-PGR environment's reproduction of "poverty culture".

It should be also emphasised that the analysis of the Kruskal-Wallis ANOVA test, in terms of the level of norms acquisition surveyed for the LAG communities from 5 voivodeships, showed that Warmińsko-Mazurskie differs from other voivodeships in two basic norms that are necessary for economic culture description: risk-taking and the level of confidence in agents outside the group. In the case of Warmińsko-Mazurskie, significant statistical differences between the regions occurred in comparison with other voivodeships in terms of norms acquisition: for risk-taking, the value of the Kruskal-Wallis test was $\mathrm{H}=33.02$ with $\mathrm{p}$-value $<0.001$; the level of trust in people outside the group was $\mathrm{H}=65.94$. The average declared level of these norms' acquisition was the lowest for the LAG community from Warmińsko-Mazurskie.

The study positively verified the hypothesis that the Warmińsko-Mazurskie Voivodeship shows statistically significant differentiation in terms of negative phenomena in economic culture potential when compared to other regions of Eastern Poland. 
Table 2. Results of the Kruskal-Wallis rank ANOVA test in terms of the surveyed norms acquisition by the LAGs communities from examined voivodships ( $\mathrm{N}=390$, total of sample)

\begin{tabular}{|c|c|c|c|c|}
\hline $\begin{array}{c}\text { Norms in } \\
\text { voivodships }\end{array}$ & $\mathrm{N}^{*}$ & Averagerank & $\begin{array}{l}\mathrm{H} \\
\text { Test statistics }\end{array}$ & p-value \\
\hline \multicolumn{5}{|l|}{ risk-taking } \\
\hline Lubelskie & 315 & 636.09 & 33.02 & $\mathrm{p}<0.05$ \\
\hline Podkarpackie & 315 & 602.02 & & \\
\hline Podlaskie & 180 & 575.68 & & \\
\hline Świętokrzyskie & 225 & 578.47 & & \\
\hline Warmińsko-Mazurskie & 135 & 453.72 & & \\
\hline \multicolumn{5}{|l|}{ openness to changes } \\
\hline Lubelskie & 315 & 655.15 & 64.93 & $\mathrm{p}<0.05$ \\
\hline Podkarpackie & 315 & 651.84 & & \\
\hline Podlaskie & 180 & 518.35 & & \\
\hline Świętokrzyskie & 225 & 515.98 & & \\
\hline Warmińsko-Mazurskie & 135 & 473.60 & & \\
\hline \multicolumn{5}{|c|}{ innovative approach in acting } \\
\hline Lubelskie & 315 & 655.67 & 38.04 & $p<0.05$ \\
\hline Podkarpackie & 315 & 617.94 & & \\
\hline Podlaskie & 180 & 533.32 & & \\
\hline Świętokrzyskie & 225 & 526.09 & & \\
\hline Warmińsko-Mazurskie & 135 & 514.66 & & \\
\hline \multicolumn{5}{|c|}{ trust in non-LAG agents/organisations, as the prospective cooperation partners } \\
\hline Lubelskie & 315 & 661.64 & 65.94 & $\mathrm{p}<0.05$ \\
\hline Podkarpackie & 315 & 632.30 & & \\
\hline Podlaskie & 180 & 539.18 & & \\
\hline Świętokrzyskie & 225 & 543.86 & & \\
\hline Warmińsko-Mazurskie & 135 & 429.77 & & \\
\hline
\end{tabular}

Source: own study based on empirical research, $\mathrm{N}^{*}=1117$ in total, Each of respondents (390) gave 3 answers to rate the sector represented and other sectors

\section{Discussion}

The results of the research were compared with the results of other authors dealing with the issues of the functioning of LAGs in Poland: Zwolińska-Ligaj and Psyk-Piotrowska (Psyk-Piotrowska, 2013; Zwolińska-Ligaj, 2018). So far, there is no foreign research on the manifestations of economic culture in LAG communities.

The presented results referring to the study on economic culture of LAG societies from the peripheral regions of Eastern Poland should be interpreted in light of the research concerning functioning LAGs in Poland in the previous period of the LEADER Programme (2007-2013). In general, it should be observed that the findings of the research conducted among LAG communities from Eastern Poland are in line with the outcomes of PsykPiotrowska's study (2013) on the meaning and specific nature of Polish LAGs in terms of social capital theory, conducted for the period of 2007-2013 among 34 LAGs from voivodeships including: Lubuskie, Opolskie, Zachodniopomorskie, Małopolskie, Podkarpackie, and Wielkopolskie. Her research showed a relatively higher level of trust in people they knew compared to their trust in strangers. While trust in those they knew was quite high, trust in local institutions, and in particular in strangers, remained at a relatively low level.

The characteristic nature of norms and values respected by LAG members in PsykPiotrowska's study (2013) were: LAG members' local patriotism, community work declared by them, and perceiving territorial partnership as a value and a norm of inter-sectoral cooperation. These are also generally in line with LAGs members' profiles surveyed in 
Eastern Poland, referring to the normative assumptions of the LEADER initiative in particular: local patriotism, partnership, sense of subjectivity, responsibility and empathy for the group, and respect for democracy in cooperation.

Psyk-Piotrowska (2013) proved that LAG members are local patriots declaring work for the whole partnership and not only for conducting their own commune's particular interests. Such motivation to act in a local group may be the factor facilitating partnership for the good of the residents, who are included in this partnership. The relatively high level of LAG social capital is, as it has been mentioned, at least partially conditioned by the sociodemographic characteristics of its members (the level of human capital).

The unfavourable cultural determinants of the LAG community in the WarmińskoMazurskie Voivodeship identified in the study will undoubtedly block the development and change of the "lagging region" status. Podkarpackie and Lubelskie Voivodeships are in a different situation. These regions and their communities will be more effective in absorbing support programmes and projects targeting lagging regions under EU cohesion policy. Similar problems and limitations of development seem to concern especially rural regions within the lagging regions of the CEE region (Bulgaria, Romania, and Hungary).

\section{Conclusion}

By answering the question of how economic culture of LAG communities from the peripheral regions of Eastern Poland is shaped, with regard to the selected attributes of human and social capital, the following was observed:

- in each of the surveyed voivodeships, there was a higher level of acquisition of norms such as diligence, code of conduct, work esteem, cost efficiency, and entrepreneurship when compared to risk-taking, openness to changes, and innovative approach to action;

- a lower level of risk-taking influences further functioning, and the level has an impact on the area of economic growth; it may also constrain the possibilities for the further functioning of these organisations, e.g. with the diminished scope of financial support under EU programmes;

- the analysis of the trust component with relation to the formerly pointed-out regularities reveals a more conservative than successive character of the represented economic cultures;

- a relatively high level of the surveyed LAG communities' social capital might be, at least partly, conditioned by the socio-demographic characteristics of their members (high level of education and attachment to their place of living)

The findings also showed the diversity of economic cultures' manifestations exhibited by LAG members in particular voivodeships despite some common features. Economic cultural attributes revealed some similarities in selected voivodeships, but, on the other hand, each voivodeship has its own uniqueness.

The normative system in particular voivodeships should be considered, in general, differentiated at a low level. The (CV) parameters were not higher than $40 \%$ (at the average/moderate level of diversity), while Podkarpackie and Lubelskie presented systems that were internally differentiated at the minimum (low (CV) up to 20\%).

Such a situation can create positive conditions for LAG development wherever the level of norms acquisition is high (mainly the Podkarpackie and Lubelskie voivodeships). However, with the average level of acquisition, their high homogeneity can impede reaching a high level of norms acquisition.

In the case of Warmińsko-Mazurskie, some clearly negative phenomena in terms of shaping economic culture potential can be observed especially when it comes to social trust risk-taking, entrepreneurship, openness to changes, and innovative approach to action. 
Researching the specificity of cultural determinants of economic behaviour of the communities of peripheral regions seems to be necessary in the context of building an appropriate convergence policy. An answer should be sought to the question of how lagging regions with a shortage of pro-development cultural features can improve their competitiveness and innovation.

The research outcomes can be a premise to suggest ways and mechanisms for the LEADER Programme's implementation at the regional level, such as:

- strengthening identification with the LEADER normative system as well as shaping the normative system in terms of values referring to the area of economic activity;

- increasing the bridging social capital component, manifested by the readiness to develop social trust beyond the group, as this in particular seems to be crucial for the ability of organisations to grow and innovativeness.

There is also the need for further research on particular LAGs in order to define the relation between LAG community economic culture and LAG impact on local and regional economic growth.

\section{Acknowledgement}

The paper was prepared under project no WNET/KEZ/ZE3 entitled: "The role of institutions and organizations in sustainable development of rural areas" implemented as part of statutory research of Pope John Paul II State School of Higher Education in Biala Podlaska, Faculty of Economics and Technical Sciences. Authors thanks CBM INDICATOR for survey data collection.

\section{References}

Abramowicz, J., Borowczak, A., Grabowska, I., Polańska, Z., Popis, Z., Kopczyńska, M., Krzewski, A., \& Ledzion, B. (2019). Raport końcowy z badania pn. Określenie optymalnego modelu funkcjonowania Lokalnych Grup Działania w nowej perspektywie finansowej oraz ocena jakości i efektywności ich funkcjonowania. Warszawa: MRiRW.

An official website of the European Union. (2021). https://enrd.ec.europa.eu/leader-clld_en , Retrieved July 5, 2021.

Anderson, C.R., Brushett, L., Gray, T.W., \& Renting, H. (2014). Working together to build cooperative food systems. Journal of Agriculture, Food Systems, and Community Development, 4 (3), 3-9. http://dx.doi.org/10.5304/jafscd.2014.043.017.

Arthur, B. (1989). Competing technologies, increasing returns and lock-in by historical events. The Economic Journal, 99 (394), 116-131. https://doi.org/10.2307/2234208.

Bartkiewicz P., Bukowski, M., Magda, I., Nazarczuk, J.M. \& Pelle, D. (2010). Warmia i Mazury 2020 - jaka droga do rozwoju? Olsztyn: IBS.

Bosworth, G., Annibal I., Carroll, T., Price, L., Sellick, J., \& Shepherd, J. (2016). Empowering local action through neo-endogenous development: The case of LEADER in England. Sociologia Ruralis, 56 (3), 427-449. https://doi.org/10.1111/soru.12089.

Chmieliński, P. (2011). On community involevement in rural development - a case of Leader programme in Poland. Economics and Sociology, 4(2), 120-128. DOI:10.14254/2071789X.2011/4-2/11.

Czapiński, J. (2008). Kapitał ludzki i kapitał społeczny a dobrobyt materialny. Polski paradoks. Zarzadzanie Publiczne, 2(4).

Diagnoza społeczna (2009), Czapiński. J., \& Panek, T. (ed.), Warszawa, Retrieved May 10, 2020, from http://www.diagnoza.com/pliki/raporty/Diagnoza_raport_2009.pdf. 
Elliott, J. (2010). Rural development programme for England 2007-2013: mid-term evaluation, (1), Hyder and ADAS.

Farole, T., Goga, S., \& Ionescu- Heroiu, M. (2018). Rethinking Lagging Regions: Using Cohesion Policy to Deliver on the Potential of Europe's Regions. World Bank Raport on European Union, Word Bank Group 2018, Retrieved July 5, 2021 from https://www.worldbank.org/en/region/eca/publication/rethinking-lagging-regions.

García-Rodríguez, F. J., Gil-Soto, E., Ruiz-Rosa, I., \& Gutiérrez-Taño, D. (2017). Entrepreneurial potential in less innovative regions: the impact of social and cultural environment. European Journal of Management and Business Economics, 26 (2), 163 179, Retrieved May 10, 2020, from https://doi.org/10.1108/EJMBE-07-2017-010.

Gardocka, A., (2005). Kultura ekonomiczna jako instytucja [in:] Kopycińska D., (ed.), Teoretyczne aspekty gospodarowania, Szczecin: Uniwersytet Szczeciński.

Gesteland, R. (2000). Różnice kulturowe a zachowania w biznesie. Warszawa: PWN.

Grabher, G. (1993). The Weakness of Strong Ties: The Lock-in of Regional Development in the Ruhr Area. London: Routledge, 255-277.

Grondona, M. (2003). Kulturowa typologia rozwoju gospodarczego [in:] Harrison L.E., Huntington S.P., (ed.), Kultura ma znaczenie, (tłumaczenie Dymczyk S.), Poznań: Wydawnictwo Zysk i S-ka.

Growiec, K., \& Growiec J. (2011). Trusting Only Whom You Know, Knowing Only Whom You Trust: The Joint Impact of Social Capital and Trust on Individuals' Economic Performance and Happiness in CEE Countries. National Bank of Poland Working Paper, 94.

Guzal-Dec, D. (2014). Partnerstwa międzysektorowe - lokalne grupy działania jako instrument wykorzystania zasobów lokalnych w procesie zrównoważonego rozwoju obszarów przyrodniczo cennych województwa lubelskiego. Roczniki Naukowe SERiA, 16(4), 109-114.

Guzal-Dec, D. (2016, April). Local Action Groups in the development of rural areas in Lubelskie voivodeship (Poland). Paper presented at the meeting of International Conference "Economic Science for Rural Development", (42), Jelgava, LLU ESAF, 6571.

Guzal-Dec, D., \& Zwolińska-Ligaj, M. (2017). The role of Local Action Groups in the process of multifunctional development of a peripheral region. A case study of the region of Lublin, Poland. Village and Agriculture, (3), 97-120. doi: 10.5604/01.3001.0014.3528.

Hałasiewicz, A. (2011). Rozwój obszarów wiejskich w kontekście zróżnicowań przestrzennych w Polsce i budowania spójności terytorialnej kraju. Retrieved May 10, 2020, from http://www.mrr.gov.pl/rozwoj_regionalny/Ewaluacja_i_analizy/Raporty_o_rozwoju/Raporty_krajowe/Documents/Ekspertyza_ Rozwoj_\%20obszarow_wiejskich_09082011.pdf.

Harrison, L.E. (2003). Dlaczego kultury nie sposób przecenić [in:] Harrison, L.E., Huntington S.P., (ed.), Kultura ma znaczenie, (tłumaczenie Dymczyk S.), Poznań: Wydawnictwo Zysk i S-ka.

Hofstede, G. (2000). Kultury i organizacje. Zaprogramowanie umystu. Warszawa: PWE.

Idczak, P. (2013). Wielowymiarowa koncepcja peryferyjności regionalnej. Identyfikacja regionów peryferyjnych $w$ Polsce. Warszawa: Difin, 84-87.

Kochanowicz, J. (2012). Wprowadzenie [in:] Kochanowicz J., Marody M., (ed.), Kultura i gospodarka, Warszawa: Wydawnictwo Naukowe SCHOLAR.

Kostro, K. (2009). Zagadnienia kulturowe w ekonomii. Gospodarka Narodowa, 3, 27-59. 
Krievina, A., Leimane, I., \& Melece, L. (2015). Role of Local Action Groups in addressing regional development and social problems in Latvia. Research for rural development, 2 , $146-153$.

Krzyminiewska, G. (2014). Rozwój kultury ekonomicznej w warunkach zróżnicowania regionalnego obszarów wiejskich. Journal of Agribusiness and Rural Development, 1.

Labianca, M., De Rubertis, S., Belligiano, A., \& Salento, A. (2016). Innovation in rural development in Puglia, Italy: Critical issues and potentialities starting from empirical evidence. Studies in Agricultural Economics, 118, 38-46. http://dx.doi.org/10.7896/j.1531

Lindsay, S. (2003). Kultura, modele umystowe $i$ dobrobyt narodowy [in:] Harrison L.E., Huntington S.P., (ed.), Kultura ma znaczenie, (tłumaczenie Dymczyk S.), Poznań: Wydawnictwo Zysk i S-ka.

MacFarland, T.W., \& Yates, J.M. (2016). Kruskal-Wallis H-Test for Oneway Analysis of Variance (ANOVA) by Ranks. [in:] Introduction to Nonparametric Statistics for the Biological Sciences Using R. Springer, Cham. Retrieved July 5, 2021 from https://doi.org/10.1007/978-3-319-30634-6_6.

Miszczuk, A. (2013). Uwarunkowania peryferyjności regionu przygranicznego. Lublin: Norbertinum.

Nembhard, J.G. (2014). Benefits and Impacts of Cooperatives. Grassroots Economic Organizing (GEO) Newsletter, (2), Theme 18.

Pilati, M., \& Hunter, A. (2020). Research for REGI Committee - EU Lagging Regions: state of play and future challeges, European Parliament, Policy Department for Structural and Cohesion Policies, Brussels, Retrieved July 5, 2021 from https://www.europarl.europa.eu/RegData/etudes/STUD/2020/652215/IPOL_STU(2020) 652215_EN.pdf European Union, 2020.

Pisani, E., Franceschetti, G., Secco, L., \& Christoforou, A. (2017). Social Capital and Local Development. From Theory to Empirics. Palgrave: Macmillan Springer.

Porter, M.E. (2003). Postawy, wartości i przekonania a makroekonomia dobrobytu [in:] Harrison L.E., Huntington S.P., (ed.), Kultura ma znaczenie, (tłumaczenie Dymczyk S.), Poznań: Wydawnictwo Zysk i S-ka.

Psyk-Piotrowska, E. (2013). Badanie kapitału społecznego LGD - uzasadnienie problemu, założenia metodologiczne, podstawowe wyniki badań. Acta Universitatis Lodziensis. Folia Sociologica, 44.

Putnam, R., (1995). Demokracja $w$ działaniu: tradycje obywatelskie we współczesnych Włoszech. Kraków: Wydawnictwo Znak.

Raport końcowy Ocena funkcjonowania lokalnych grup działania realizujacych lokalna strategię rozwoju w ramach PROW 2007-2013, Warszawa 2012, 85. Retrieved July 5, 2020 from http://www.mojregion.eu/files/PROW/Dokumenty_ks/dokumenty\%20inne/Raport_LG D_i_studia_przypadku.pdf.

The act of law concerning CLLD (Community-led Local Development) (Dz.U. 2015 poz. 378 ze zm.

Zwolińska-Ligaj, M. (2018). Kształtowanie lokalnych systemów innowacji jako sposób realizacji koncepcji inteligentnego rozwoju na przykładzie regionów peryferyjnych. SERIA MONOGRAFIE I ROZPRAWY nr 9. Biała Podlaska: Wydawnictwo PSW JPII w Białej Podlaskiej. 